\title{
Hair Whorl Position as a Predictor of Learning Ability and Locomotor Behavior in Cattle?
}

\author{
J. BROUČEK, M. UHRINČAŤ, P. KIŠAC, A. HANUS \\ Research Institute of Animal Production, Nitra, Slovak Republic \\ Received April 1, 2004 \\ Accepted October 26, 2004
}

\begin{abstract}
Brouček J., M. Uhrinčat, P. Kišac, A. Hanus: Hair Whorl Position as a Predictor of Learning Ability and Locomotor Behavior in Cattle? Acta Vet Brno 2004, 73: 455-459.

The aim of our work was to investigate the hypothesis that the speed of solving the maze tests and locomotor behavior of heifers in open-field tests are affected by the height location of facial whorl. Fifty-eight Holstein heifers were used. Maze learning was observed at the age of 15 weeks, and an open-field test was applied at two ages, 16 weeks and 18 months. Whorl placement was recorded by one person as each heifer entered the scale. The hair whorl position was determined on the basis of two patterns: A) hair whorl high, middle and low and B) hair whorl high and low. Heifers with a high hair whorl were the fastest $(77.8 \pm 84.3 \mathrm{~s})$ and heifers with a middle hair whorl the slowest $(87.3$ $\pm 100.3 \mathrm{~s}$ ) in the A pattern during the maze tests. In the B whorl pattern, heifers with a high hair whorl ran across the maze in $84.5 \pm 95.2 \mathrm{~s}$ and heifers with a low hair whorl in $84.1 \pm 97.9 \mathrm{~s}$. The number of crossed squares in a 5-minute open-field test in the A pattern was the non-significantly highest in heifers with a high hair whorl (43.4) at the age of 16 weeks. In the B whorl pattern, heifers with a high hair whorl were also more mobile, but neither differences in individual minutes nor in the whole 5 minutes were significant. Heifers with a high hair whorl displayed the strongest locomotory behavior (37.6 squares) and heifers with a low hair whorl (30.8) were the slowest in the A pattern at the age of 18 months. The differences were not significant. In the B whorl pattern, heifers with a high hair whorl crossed more squares, but the difference was not significant in comparison with heifers with a low hair whorl. We found that the time of traversing the maze and the locomotor activity in open-field test may not be influenced in the dairy cattle by the height facial whorl position.

Cattle, hair whorl, reversal learning, open-field
\end{abstract}

For the sake of the safety of veterinarians and workers during the handling or treatment of cattle, especially those kept in big herds, on pasture, but also during first milkings of firstcalf cows, it is important to anticipate whether their behavior will change unexpectedly. Fast reactions are induced above all by animal temperament. However, it takes time to determine temperament. For example, animals are evaluated according to flight speed scores or on the basis of their reactions while they are restricted in a squeeze chute (Burrow 1997). For temperament assessing, it would be very useful to use some sign on the animal's body or even better on the head. Hair whorl position on the forehead may be of value in selecting breeding cattle for a calm temperament. Twenty-seven percent $(378 \mathrm{hd})$ with a single hair whorl in the middle of the forehead had strong side preferences (i.e. were sided). Forty-five cows with two hair whorls on the forehead were significantly less sided than the rest of the population. This confirms observations from horse trainers that horses with two hair whorls are less handed (Tanner et al. 1994). Grandin et al. (1995) rated a total of 1500 cattle weighing $180-360 \mathrm{~kg}$ about temperament on a four-point scale. Seventy-two percent of the cattle were European $\times$ British breed crosses and $28 \%$ were Zebu $\times$ dairy breed crosses from Mexico. Cattle with a hair whorl located above the eyes became significantly more agitated while they were restrained in a squeeze chute compared to cattle with a hair whorl located either between the eyes or below the eyes. For both the Bos taurus and Bos indicus crossbreeds, animals with hair whorls located below the eyes were rated calmer.

\begin{tabular}{l}
\hline Address for correspondence: \\
Ing. Jan Brouček, DrSc. \\
Research Institute of Animal Production \\
2, PO Box 30 C \\
VUZV, Hlohovská 2, 94992 Nitra \\
Slovak Republik
\end{tabular}
Phone: +421376546280

Fax: +421 376546483

E-mail: broucek@ vuzv.sk
http://www.vfu.cz/acta-vet/actavet.htm 
In the other research of US authors, the relationship between hair whorl position and temperament was assessed for 1,636 beef type (Bos taurus, Bos indicus), dairy breeds and their crosses (Lanier et al. 1999). Animals with higher activity of locomotor behavior in the auction ring had higher whorl positions $(P<0.01)$. Holsteins were calmer than beef type cattle $(P<0.01)$ in the ring. Differences between ring score and hair whorl height $(P=0.01)$ were found. In the another work Lanier et al. (2001) observed 75\% Bos taurus beef breeds, $21 \%$ Holstein dairy cattle, $3 \%$ Bos indicus beef breeds, and $1 \%$ non-Holstein dairy breeds. Ten percent of cattle surveyed had no facial hair whorl, while $86 \%$ had a single spiral hair whorl, of which $47 \%$ had middle-middle whorl placement (point of intersection of vertical and horizontal location). Animals with a high whorl position or no hair whorl had higher temperament scores $(P=0.01)$. Temperament scores showed that Holsteins were calmer than beef cattle $(P<0.01)$.

Randle (1998) assessed the relationship between hair whorl position and behavior in 57 Bos taurus cattle. Response to a novel object, operant conditioning and response to a familiar human were not associated with whorl position. Individuals with mid whorls exhibited significantly greater flight distances to an unfamiliar human than did individuals with low whorls .

The aim of this paper was to investigate the hypothesis that the height locations of hair whorl influences learning ability and locomotor behavior of heifers in the maze and unknown environment.

\section{Materials and Methods}

Fifty-eight Holstein heifers were used. They were reared in individual hutches from the second day of life to weaning at the age of 8 weeks. They were moved into the heifers-barn with loose housing after weaning. They were kept in loose housing in groups according to age after weaning. The heifers originated from 2 sires (BS-6, $\mathrm{n}=27$ and STB-9, $\mathrm{n}=31)$. Differences between sire lineages were not significant in any behavior variable $(P<0.1)$.

Whorl placement was recorded by one person as each heifer entered the scale. The hair whorl position was determined on the basis of two patterns: A) hair whorl high, middle and low and B) hair whorl high and low.

A) The hair whorl position was categorized as: "high" if the center was above the top of eyes; "middle" if the center was located between the top of the eyes and the bottom of the eyes; "low" if the center was located below the bottom of the eyes (Grandin et al. 1995).

B) The hair whorl position was categorized high or low if the whorl was above or below the eye line.

We found 7 heifers with a high hair whorl, 36 heifers with a middle hair whorl and 15 heifers with a low hair whorl in the A pattern. In the B pattern there were 21 heifers with a high and 37 heifers with a low hair whorl position. All whorls were of single round type.

The maze learning ability tests were performed with heifers at the age of 15 weeks. The 6 -unit maze was constructed in the pen $16.4 \times 4.5 \mathrm{~m}$ of $1.5 \mathrm{~m}$ high steel fence covered with black plastic sheet. Five barriers were installed inside which marked the beginning and the end of the route and also particular parts of the maze. In the exit part a bucket with feed mixture was placed. Time was recorded from the moment of the entry to the exit.

The calves had to solve two tasks on two consecutive days. On the first observation day (learning task), the calves were tested five times, three runs in the morning and two runs in the afternoon. The first test was for training. On the second day (reversal task), there were two runs in the morning and two runs in the afternoon. In the learning task, the passage was open on the left side, and on the right side (reversal task) on the next day.

Each calf was put to the maze entrance by familiar handler and the door was closed behind it. If the calf was in the maze longer than 3 minutes, it was forced gently to movement. The calf was allowed to eat for only a few seconds, whereupon it was led out of the maze to repeat the procedure. All behaviors were recorded by a video camera.

An open-field test was applied at two ages: A1 (16 weeks) and A2 (18 months) in an arena marked off into 9 squares. In A1, the size of arena was $4.5 \times 4.5 \mathrm{~m}$, at the $\mathrm{A} 2$ age $10 \times 10 \mathrm{~m}$. The calves were given one 5 -min test (morning). All behaviors, including vocalizations, defecations, urinations were recorded by a video camera in all tests.

The data were analyzed with a statistical package STATISTIX (Anonym 1996). The normal distribution of data was evaluate by Wilk-Shapiro/Rankin Plot procedure. All data had a parametric distribution. Among-group comparisons in distribution A were analyzed using a General linear model analysis of variance (General AOV/AOCV). Significant differences among means were tested by Bonferroni's test. Differences in distribution B were calculated using Student $t$-test. 


\section{Results}

Maze

Differences in the average time of traversing the maze in all tests were non-significant in the A pattern (high, middle, low). Heifers with a high hair whorl were the fastest (77.8 $\pm 84.3 \mathrm{~s})$ and heifers with a middle hair whorl the slowest $(87.3 \pm 100.3 \mathrm{~s})$. The longest times of crossing the maze were recorded in the heifers with low position of hair whorl $(75.1 \mathrm{~s})$ and the shortest time in the heifers with a middle hair whorl (59.5 s ) during the learning task, but differences among groups of animals were not significant (Table 1). In the reversal task, heifers with a low hair whorl were the fastest (84.7 s) and heifers with a middle hair whorl the slowest (115.4 s).

Table 1

Average times of traversing the maze (s)

\begin{tabular}{lccccc}
\hline \multirow{2}{*}{ Place } & \multirow{2}{*}{} & \multicolumn{2}{c}{ Pattern A } & \multicolumn{2}{c}{ Pattern B } \\
\cline { 3 - 6 } & & $1^{\text {st }}$ task & $2^{\text {nd }}$ task & $1^{\text {st }}$ task & $2^{\text {nd }}$ task \\
\hline $\mathrm{H}$ & 7 & $65.6 \pm 55.6$ & $90.1 \pm 61.2$ & $53.4 \pm 48.9$ & $101.7 \pm 81.9$ \\
$\mathrm{M}$ & 36 & $59.5 \pm 60.1$ & $115.4 \pm 87.8$ & & \\
$\mathrm{~L}$ & 15 & $75.1 \pm 63.2$ & $84.7 \pm 76.3$ & $66.6 \pm 64.1$ & $102.3 \pm 77.2$ \\
\hline Significance & N.S & N.S & N.S & N.S
\end{tabular}

Place $=$ placement of the whorl $;=$ high; $M=$ middle $;=$ low; $n=$ number of animals

In the B whorl pattern (high and low) we did not find any significant differences (Table 1). Heifers with a high hair whorl ran across the maze in $84.5 \pm 95.2 \mathrm{~s}$ (an average time of all tests) and heifers with a low hair whorl in $84.1 \pm 97.9 \mathrm{~s}$. During the learning task, heifers with a high hair whorl had slightly faster time for traversing the maze (53.4 s) then animals with a low position of whorl (66.6 s).

Open-field at the age of 16 weeks

The number of crossed squares in a 5-minute test in the A pattern (Table 2) was the highest in heifers with a high hair whorl (43.4), while the lowest number was found in heifers with a low hair whorl (37.8). A statistically significant difference $(P<0.05)$ was only in the third minute of the open-field test, namely between the group with a high hair whorl and the group with a low hair whorl ( 8.4 vs. 5.3). In the $\mathrm{B}$ whorl pattern, heifers with a high hair whorl were also more mobile (Table 2), but neither differences in individual minutes nor in the whole 5 minutes were significant.

Table 2

Number of grid-crossings during open-field test at the age of 16 weeks

\begin{tabular}{lccccc}
\hline \multirow{2}{*}{ Place } & \multirow{2}{*}{$\mathrm{n}$} & \multicolumn{2}{c}{ Pattern A } & \multicolumn{2}{c}{ Pattern B } \\
\cline { 3 - 6 } & & $1^{\text {st }}$ minute & 5 minutes & $1^{\text {st }}$ minute & 5 minutes \\
\hline $\mathrm{H}$ & 7 & $14.6 \pm 8.1$ & $43.4 \pm 19.8$ & $14.6 \pm 6.9$ & $41.0 \pm 16.2$ \\
$\mathrm{M}$ & 36 & $13.5 \pm 6.4$ & $39.4 \pm 19.8$ & & \\
$\mathrm{~L}$ & 15 & $13.0 \pm 6.3$ & $37.8 \pm 19.7$ & $12.9 \pm 6.3$ & $38.6 \pm 21.2$ \\
\hline Significance & N.S. & N. S. & N. S. & N. S.
\end{tabular}

Place $=$ placement of the whorl $\mathrm{H}=$ high; $\mathrm{M}=$ middle $\mathrm{L}=$ low $\mathrm{n}=$ number of animals

Open-field at the age of 18 months

Heifers with a middle hair whorl displayed the greatest locomotory behavior (37.6) and heifers with a low hair whorl (30.8) were the slowest. However, the differences were not significant (Table 3). In the B whorl pattern, heifers with a high hair whorl crossed more 
squares, and the difference was not significant in comparison with heifers with a low hair whorl (Table 3).

Table 3

Number of grid-crossings during open-field test at the age of 18 months

\begin{tabular}{lccccc}
\hline \multirow{2}{*}{ Place } & $\mathrm{n}$ & \multicolumn{2}{c}{ Pattern A } & \multicolumn{2}{c}{ Pattern B } \\
\cline { 3 - 6 } & & $1^{\text {st }}$ minute & 5 minutes & $1^{\text {st }}$ minute & 5 minutes \\
\hline $\mathrm{H}$ & 7 & $8.8 \pm 5.6$ & $34.7 \pm 18.3$ & $9.3 \pm 4.6$ & $36.9 \pm 18.1$ \\
$\mathrm{M}$ & 36 & $8.2 \pm 4.4$ & $37.6 \pm 16.3$ & & \\
$\mathrm{~L}$ & 15 & $7.5 \pm 3.2$ & $30.8 \pm 11.8$ & $7.4 \pm 3.9$ & $34.7 \pm 14.1$ \\
\hline Significance & N.S. & N.S. & N.S. & N.S.
\end{tabular}

Place $=$ placement of the whorl $\mathrm{H}=$ high $; \mathrm{M}=$ middle; $\mathrm{L}=$ low $\mathrm{n}=$ number of animals

\section{Discussion}

Attention to the significance of the hair whorl in cattle has been subject to intensive research by authors from the scientific team of Dr. Grandin (Colorado State University). According to their results, facial hair whorls in cattle may be a useful management tool in assessing which animals may become fearful or disturbed in novel environments such as feedlots, auctions and slaughter houses (Lanier et al. 2001). Cattle with hair whorls high on the forehead appear to be more likely to panic during restraint compared to cattle with low hair whorls (Grandin et al. 1995).

In our evaluation we could not statistically comfirm the hypothesis that heifers that have a whorl above the eye line are faster and more excitable than those with a whorl under the eye line. We found that animals with the whorl above the eye line tranversed the maze faster and manifested a more intensive locomotor behavior in open-field tests, but differences among groups were not significant.

How can we explain this? We used Holstein heifers, which we fed intensively, they were used to a frequent treatment, were used to the handler, and so they in fact had a good relationship with humans. The cattle observed in the study of Grandin et al. (1995) were extensively raised and had a large flight zone when approached by people.

Casual observations indicate that the relationship between hair whorl position and temperament is most easily observed in cattle that do not have daily close contact with people (Grandin et al. 1995). Moreover, animals used by Grandin were European $\times$ British breed crosses and Zebu $\times$ dairy breed crosses.

Our animals came from the same housing and were fed by the same handler, so it is unlikely that they had different previous handling experiences. In contrast - animals that are gathered at auction, live in big herds and are influenced also by a complicated social environment.

Hair whorl position significantly affected temperament rating during exiting from the squeeze chute in both Bos taurus and Bos indicus $\times$ Bos taurus crossbreeds $(P<0.04)$ (Grandin et al. 1995). Last but not least, this was influenced by the number of used animals. It is highly probable that if we had used a higher number of animals, the results would have been significant.

In conclusion, heifers with a high hair whorl were the faster, but not significantly faster during the maze tests. The results indicated that the height position of hair whorl may have an impact on their maze behavior. The number of crossed squares in the open-field test was non-significantly highest in heifers with a high hair whorl at the age of 16 weeks. Heifers with a high hair whorl displayed the greatest locomotory behavior at the age of 18 months, but the difference was not significant either. We can conclude that the time of traversing the maze and the locomotor activity of dairy cattle in open-field tests may not be influenced by the height of their facial whorl position. 


\section{Předpovídá (naznačuje) pozice vlasového víru u skotu schopnost učení anebo pohybové chování?}

Cílem práce bylo zkoumat hypotézu, že rychlost řešení bludištových testů a pohybové chování jalovic v open-field testech jsou ovlivněny výškovou pozicí obličejového víru. Bylo použitých 58 jalovic plemena Holštýn. Bludištové chování bylo sledováno ve věku 15 týdnů, open-field test byl aplikován dvakrát, ve věku 16 týdnů a 18 měsíců. Umístění víru bylo zaznamenávané jednou osobou při vážení. Pozice víru byla určována na základě dvou vzorů: A) vír nahoře, ve středu a dole $\mathrm{a} B$ ) vír nahoře nebo dole. Jalovice s vírem nahoře byly ve vzoru A během bludištových testů nejrychlejší (77.8 $\pm 84.3 \mathrm{~s})$ a jalovice s vírem ve středu nejpomalejší $(87.3 \pm 100.3 \mathrm{~s})$. Ve vzoru $\mathrm{B}$, přeběhly jalovice s vírem nahoře za $84.5 \pm 95.2$ $\mathrm{s}$ a jalovice $\mathrm{s}$ vírem dole za $84.1 \pm 97.9 \mathrm{~s}$. Ve věku 16 týdnů byl počet překročených čtverců za 5 minut open-field testu ve vzoru A neprůkazně vyšší u jalovic s vírem nahoře (43.4). Ve vzoru B byly jalovice s vírem nahoře též více pohyblivější, ale ani jeden rozdíl v jednotlivých minutách pětiminutového testu nebyl průkazný. Ve věku 18 měsíců projevily ve vzoru A jalovice s vírem nahoře výraznější pohybové chování (37.6 čtverců) a jalovice s vírem dole (30.8) byly nejpomalejší. Rozdíly nebyly průkazné. Ve vzoru B překročily jalovice s vírem nahoře více čtverců, ale rozdíly nebyly v porovnání s jalovicemi s vírem dole průkazné. Zjistili jsme, že čas přeběhnutí bludištěm a pohybová aktivita v open-field testu nejsou u mléčného skotu ovlivněné výškovým umístěním obličejového chlupového víru.

\section{References}

ANONYM 1996: Statistix for Windows. User`s Manual. Analytical Software, P.O.Box 12185, Tallahassee, FL 32317-2185, USA, ISBN 1-881789-04-7, 333 p.

BURROW, HM 1997: Measurements of temperament and their relationships with performance traits of beef cattle. Animal Breeding Abstracts 65: 477-495

GRANDIN, T, DEESING, MJ, STRUTHERS, JJ, SWINKER, AM 1995: Cattle with hair whorl patterns above the eyes are more behaviorally agitated during restraint. Appl Anim Behav Sci 46: 117-123

LANIER, JL, GRANDIN, T, GREEN, RD, AVERY, D, MCGEE, K 1999: Cattle hair whorl position and temperament in auction houses. J Dairy Sci 82, Suppl. 1: p. 147

LANIER, JL, GRANDIN, T, GREEN, RD, AVERY, D, MCGEE, K 2001: A note on hair whorl position and cattle temperament in the auction ring. Appl Anim Behav Sci 73: 93-101

RANDLE, HD 1998: Facial hair whorl position and temperament in cattle. Appl Anim Behav Sci 56: 139-147

TANNER, M, GRANDIN, T, CATTELL, M, DEESING, MJ 1994: The relationship between facial hair whorls and milking parlor side preferences. J Anim Sci 72, Suppl. 1/ J Dairy Sci 77, Suppl. 1: p. 207 